\title{
Pola bakteri aerob yang berpotensi menyebabkan infeksi nosokomial di ruang neonatal intensive care unit (NICU) RSAD Robert Wolter Mongisidi Manado
}

\author{
${ }^{1}$ Marshall C. Waworuntu \\ ${ }^{2}$ Fredine E.S Rares \\ ${ }^{2}$ Heriyannis Homenta
}

\author{
${ }^{1}$ Kandidat Skripsi Fakultas Kedokteran Universitas Sam Ratulangi Manado \\ ${ }^{2}$ BagianMikrobiologi Fakultas Kedokteran Universitas Sam Ratulangi Manado \\ Email: marshallchw@gmail.com
}

\begin{abstract}
Nosocomial infection is an infection which occurs in the hospital caused by microbateria from the hospital. Nosocomial infections that occur in the newborn is a serious problem in every hospital. Neonatal Intensive Care Unit (NICU) is a care unit for newborn who needs special care. Nosocomial infections often occur, especially in infants hospitalized in NICU. The purpose of this research is to determine the pattern of aerobic bacteria that could potentially cause nosocomial infections in NICU RSAD Robert Wolter Monginsidi Manado. The research used descriptive cross sectional method. The amount of the samples are 29 and was taken according to category of the treatment room, room instruments, medical equipments and air. Based on the results, there are 9 species of bacterias included Enterobacter cloacae (27\%), Staphylococcus sp (17\%), Bacillus subtilis (13\%), Klebsiella pneumoniae (13\%), Serratia liquefaciens (10\%), Serratia marcescens (7\%), Enterobacter aerogenes (7\%), Neisseria sp (3\%) and Escherichia coli (3\%). The most bacteria that could potentially cause nosocomial infections were Enterobacter cloacae.
\end{abstract}

Keywords: nosocomial infections, NICU, aerob bacteria

\begin{abstract}
Abstrak: Infeksi nosokomial adalah suatu infeksi yang didapat atau terjadi saat pasien dirawat di rumah sakit oleh kuman yang berasal dari rumah sakit. Infeksi nosokomial yang terjadi pada bayi baru lahir merupakan masalah yang serius disetiap rumah sakit. Neonatal Intensive Care Unit (NICU) merupakan unit perawatan untuk bayi baru lahir yang memerlukan perawatan khusus. Infeksi nosokomial sering terjadi terutama pada bayi yang dirawat di NICU. Tujuan penelitian ini yaitu untuk mengetahui pola bakteri aerob yang berpotensi menyebabkan infeksi nosokomial di ruangan NICU RSAD Robert Wolter Mongisidi Manado. Penelitian ini menggunakan metode deskriptif dengan pendekatan potong lintang (cross sectional). Sampel yang diteliti berjumlah 29 sampel dan di ambil berdasarkan kategori ruang perawatan, perabotan ruangan, peralatan medis dan udara. Berdasarkan hasil penelitian ditemukan 9 spesies bakteri yaitu Enterobacter cloacae (27\%), Staphylococcus sp (17\%), Bacillus subtilis (13\%), Klebsiella pneumoniae (13\%), Serratia liquefaciens (10\%), Serratia marcescens (7\%), Enterobacter aerogenes (7\%), Neisseria sp (3\%) dan Escherichia coli (3\%). Bakteri yang paling banyak ditemukan adalah Enterobacter cloacae.

Kata kunci: infeksi nosokomial, NICU, bakteri aerob
\end{abstract}

Infeksi nosokomial adalah suatu infeksi yang didapat atau terjadi saat pasien dirawat di rumah sakit oleh kuman yang berasal dari rumah sakit dikenal dengan nama Hospital Acquired Infection. ${ }^{1}$ Manifestasi penyakit dapat terjadi di rumah sakit tetapi dapat juga di luar rumah sakit apabila inkubasi lebih lama dari masa tinggalnya di rumah sakit. ${ }^{2}$

Infeksi nosokomial salah satu dari penyebab peningkatan mortalitas dan morbiditas di ruang neonatal intensive care 
unit (NICU). Insidens dari infeksi nosokomial bervariasi bergantung dari faktor lingkungan dan perbedaan dalam praktek medis. $^{3}$

Biaya perawatan dari infeksi yang didapat di rumah sakit dan infeksi yang terkait pelayanan kesehatan lainnya cukup besar. Infeksi ini telah mengenai sebanyak 1,7 juta pasien dengan biaya sekitar 28-30 milyar dollar dan 99.000 jiwa di rumah sakit AS setiap tahunnya. ${ }^{4}$

Kontrol terhadap infeksi nosokomial menjadi efektif apabila mengetahui epidemiologi infeksi rumah sakit untuk memahami faktor-faktor yang berhubungan dengan infeksi nosokomial. ${ }^{5}$

Kejadian infeksi nosokomial di Indonesia yaitu di 10 RSU pendidikan cukup tinggi yaitu 6-16\% dengan rata-rata 9,8\% pada tahun $2010 .{ }^{6}$ Informasi tentang angka kejadian infeksi nosokomial di BLU RSUP Prof. DR. R. D. Kandou Manado bulan Juli - Desember 2012 ialah infeksi daerah luka operasi sebanyak $3,4 \%$, ISK $2,7 \%$, infeksi aliran darah primer $6,4 \%$, infeksi dekubitus $0,7 \%{ }^{7}$

Sebagian besar infeksi nosokomial terjadi pada bayi prematur atau bayi yang membutuhkan perawatan intensif di Neonatal Intensive Care Unit (NICU). Faktor risiko untuk infeksi nosokomial pada bayi ini meliputi prematuritas, BBLR, prosedur invasif, kateter pembuluh darah, sering menggunakan antibiotik spektrum luas dan berkepanjangan tinggal di rumah sakit. ${ }^{8,9}$

Berdasarkan data yang dikumpulkan secara restrospektif selama 2 tahun di RSAB Harapan Kita, Jakarta, terdapat peningkatan angka kejadian infeksi dari $9 \%$ pada hari I menjadi $63 \%$ pada perawatan hari ke 3-5 di NICU. ${ }^{10}$

Berdasarkan hasil penelitian yang dilakukan di ruang Neonatal Intensive Care Unit (NICU) Rumah Sakit Umum Daerah Dr. H. Abdul Moeloek Bandarlampung, didapatkan hasil identifikasi bakteri Staphylococcus aureus. ${ }^{11}$ Hasil penelitian di ruang Neonatal Intensive Care Unit (NICU) BLU RSUP Prof. DR. R. D. Kandou Manado, didapatkan bakteri non patogen Bacillus subtilis dan bakteri bersifat patogen Klebsiella pneumoniae, Serratia liquefaciens, Proteus mirabilis dan Proteus vulgaris. ${ }^{12}$

Pemeriksaan mikrobiologi lingkungan yang dilakukan secara berkala, dapat memberi data tentang pola dan populasi mikroorganisme di rumah sakit sehingga dapat dibuat kebijakan dan penggunaan disinfektan yang tepat serta mencegah infeksi nosokomial. ${ }^{13}$

\section{METODE PENELITIAN}

Penelitian ini bersifat deskriptif cross sectional dengan pendekatan prospektif untuk meneliti pola bakteri aerob yang berpotensi menyebabkan infeksi nosokomial di ruang Neonatal Intensive Care Unit (NICU) RSAD Robert Wolter Mongisidi Manado. Isolasi dan Identifikasi sampel dilakukan di Laboratorium Mikrobiologi Fakultas Kedokteran Universitas Sam Ratulangi Manado.

\section{HASIL PENELITIAN}

Pengambilan sampel pada ruangan Neonatal Intensive Care Unit (NICU) BLU RSUP Prof. Dr. R. D Kandou Manado menghasilkan sebanyak 30 sampel (Tabel $1)$.

Tabel 1. Kategori Pengambilan Sampel

\begin{tabular}{|c|c|c|}
\hline Kategori & Sampel & Jumlah \\
\hline $\begin{array}{c}\text { Ruang } \\
\text { Perawatan }\end{array}$ & Dinding, Lantai & 9 \\
\hline $\begin{array}{c}\text { Perabotan } \\
\text { Ruangan }\end{array}$ & $\begin{array}{l}\text { Timbangan, } \\
\text { Tempat Tidur }\end{array}$ & 2 \\
\hline $\begin{array}{l}\text { Peralatan } \\
\text { Medis }\end{array}$ & $\begin{array}{l}\text { Inkubator, } \\
\text { Kanul } \mathrm{O}_{2} \\
\text { Selang } \mathrm{O}_{2}\end{array}$ & 3 \\
\hline Udara & $\begin{array}{c}\text { Pagi, Siang, } \\
\text { Sore }\end{array}$ & 15 \\
\hline Total & & 29 \\
\hline
\end{tabular}

Tabel 2 menunjukkan bahwa dari 29 sampel yang diteliti, bakteri yang tumbuh pada Agar Nutrien berjumlah 29 sampel (100\%), Agar Mac Conkey berjumlah 20 sampel (69\%), dan Agar Darah berjumlah 29 sampel $(100 \%)$. 
Tabel 2. Distribusi Hasil Isolasi

\begin{tabular}{ccccc}
\hline Media Isolasi & \multicolumn{2}{c}{ Hasil } & \multicolumn{2}{c}{$(\%)$} \\
\cline { 2 - 5 } & AP & TAP & AP & TAP \\
Nutrient Agar & 29 & - & 37 & - \\
Mac Conkey & 21 & 8 & 26 & 8 \\
Agar & & & & \\
Agar Darah & 29 & - & 37 & - \\
Total & 79 & 8 & 100 & 100 \\
\hline
\end{tabular}

Tabel 3 menunjukkan bahwa pada pewarnaan Gram didapatkan bakteri yang paling banyak ditemukan adalah bakteri Gram negatif yaitu sebanyak 20 sampel, bakteri Gram positif sejumlah 9 sampel.

Tabel 3. Pewarnaan Gram

\begin{tabular}{ccc}
\hline $\begin{array}{c}\text { Pewarnaan } \\
\text { Gram }\end{array}$ & $\begin{array}{c}\text { Jumlah } \\
\text { Sampel }\end{array}$ & $(\boldsymbol{\%})$ \\
\hline $\begin{array}{c}\text { Bakteri Gram } \\
\text { positif }\end{array}$ & 9 & 31 \\
$\begin{array}{c}\text { Bakteri Gram } \\
\text { negatif } \\
\text { Total }\end{array}$ & 20 & 69 \\
\hline
\end{tabular}

Tabel 4 menyajikan total bakteri yang ditemukan adalah 30 bakteri. Pada hasil identifikasi bakteri ditemukan 9 spesies bakteri. Enterobacter cloacae paling banyak ditemukan yaitu 8 sampel $(27 \%)$. Untuk kategori ruang perawatan terbanyak terdapat bakteri Bacillus subtilis untuk sampel lantai dan Enterobacter cloacae untuk sampel dinding. Untuk kategori perabotan ruangan terdapat bakteri Serratia marcescens 1 sampel (50\%) dan Escherichia coli 1 sampel (50\%).

Tabel 4. Hasil Identifikasi Bakteri Secara Keseluruhan

\begin{tabular}{ccc}
\hline Bakteri & Jumlah & $(\boldsymbol{\%})$ \\
\hline Enterobacter cloacae & 8 & 27 \\
Staphylococcus sp & 5 & 17 \\
Bacillus subtilis & 4 & 13 \\
Klebsiella pneumoniae & 4 & 13 \\
Serratia liquefaciens & 3 & 10 \\
Serratia marcescens & 2 & 7 \\
Enterobacter aerogenes & 2 & 7 \\
Neisseria sp & 1 & 3 \\
Eschericia coli & 1 & 3 \\
Total & 30 & 100 \\
\hline
\end{tabular}

Tabel 5. Pertumbuhan Bakteri Sampel Dinding

\begin{tabular}{ccc}
\hline Bakteri & Jumlah & $\mathbf{( \% )}$ \\
\hline Enterobacter & 2 & 50 \\
$\quad$ cloacae & & \\
Enterobacter & 1 & 25 \\
aerogenes & & \\
Neisseria $s p$ & 1 & 25 \\
$\quad$ Total & 4 & 100 \\
\hline
\end{tabular}

Tabel 6. Pertumbuhan Bakteri Sampel Lantai

\begin{tabular}{ccc}
\hline Bakteri & Jumlah & Persentase(\%) \\
\hline Bacillus & 3 & 50 \\
subtillis & & \\
Klebsiella & 2 & 33 \\
pneumoniae & 1 & 17 \\
Staphyloccocus & & \\
sp & & 100 \\
Total & 6 & \\
\hline
\end{tabular}

Untuk kategori peralatan medis ditemukan bakteri Klebsiella pneumoniae 2 sampel $(66,5 \%)$ dan Enterobacter cloacae 1 sampel $(33,5 \%)$.

Tabel 7. Pertumbuhan Bakteri Sampel Kategori Perabotan Ruangan

\begin{tabular}{ccc}
\hline Bakteri & Jumlah & $(\%)$ \\
\hline $\begin{array}{c}\text { Serratia } \\
\text { marcescens }\end{array}$ & 1 & 50 \\
$\begin{array}{c}\text { Escherichia } \\
\text { coli }\end{array}$ & 1 & 50 \\
Total & 2 & 100 \\
\hline
\end{tabular}

Tabel 8. Pertumbuhan Bakteri Sampel Kategori Peralatan Medis

\begin{tabular}{ccc}
\hline Bakteri & Jumlah & $(\boldsymbol{\%})$ \\
\hline $\begin{array}{c}\text { Klebsiella } \\
\text { pneumoniae } \\
\text { Enterobacter } \\
\text { cloacae } \\
\text { Total }\end{array}$ & 2 & 66,5 \\
\hline
\end{tabular}

Tabel 9 menunjukkan pertumbuhan 3 jenis bakteri yaitu Serratia liquefaciens 3 sampel (60\%), Serratia marcescens (20\%), dan Stahylococcus sp (20\%).

Tabel 10 menunjukkan pertumbuhan 3 jenis bakteri yaitu Enterobacter cloacae 3 sampel (60\%), Enterobacter aerogenes (20\%), dan Bacillus subtilis (20\%). 
Tabel 9. Pertumbuhan Bakteri Sampel Udara Pagi

\begin{tabular}{ccc}
\hline Bakteri & Jumlah & $(\boldsymbol{\%})$ \\
\hline $\begin{array}{c}\text { Serratia } \\
\text { liquefaciens }\end{array}$ & 3 & 60 \\
Serratia & 1 & 20 \\
marcescens & & \\
Staphylococcus sp & 1 & 20 \\
Total & 5 & 100 \\
\hline
\end{tabular}

Tabel 10. Pertumbuhan Bakteri Sampel Udara Siang

\begin{tabular}{ccc}
\hline Bakteri & Jumlah & $(\%)$ \\
\hline Enterobacter & 3 & 60 \\
$\quad$ cloacae & & \\
Enterobacter & 1 & 20 \\
aerogenes & & \\
Bacillus subtilis & 1 & 20 \\
Total & 5 & 100 \\
\hline
\end{tabular}

Terdapat 3 jenis bakteri yang diperoleh dari sampel udara sore seperti yang ditunjukkan pada tabel 11 yaituStaphyloccocus sp $(60 \%)$ dan Enterobacter cloacae (40\%). Untuk Kategori udara, bakteri terbanyak yaitu Enterobacter cloacae sebanyak 5 sampel.

Tabel 11. Pertumbuhan Bakteri Sampel Udara Sore

\begin{tabular}{ccc}
\hline Bakteri & Jumlah & $(\boldsymbol{\%})$ \\
\hline $\begin{array}{c}\text { Staphylococcus sp } \\
\text { Enterobacter } \\
\text { cloacae }\end{array}$ & 3 & 60 \\
Total & 2 & 40 \\
\hline
\end{tabular}

\section{BAHASAN}

Berdasarkan penelitian yang dilakukan di ruang Neonatal Intensive Care Unit (NICU), bakteri yang tumbuh pada agar nutrien berjumlah 29 sampel, agar Mac conkey 20 sampel dan agar darah berjumlah 29 sampel. Dari hasil identifikasi berupa pewarnaan Gram dan uji biokimia ditemukan 9 jenis bakteri. Bakteri Gram positif terdiri dari Staphylococcus sp (17\%) dan Bacillus subtilis (13\%), sedangkan bakteri Gram negatif terdiri dari Enterobacter cloacae (27\%), Klebsiella pneumoniae (13\%), Serratia liquefaciens (10\%), Serratia marcescens (7\%),
Enterobacter aerogenes (7\%), Neisseria sp (3\%), Escherichia coli (3\%).

Penelitian tentang pola bakteri aerob yang menyebabkan infeksi nosokomial di ruang Neonatal Intensive Care Unit (NICU) RSUP Prof. Dr.R.D.Kandou Manado pada tahun 2015 ditemukan bakteri terbanyak yaitu Bacillus subtilis, ${ }^{14}$ pada penelitian ini Enterobacter cloacae merupakan bakteri terbanyak ditemukan di ruang Neonatal Intensive Care Unit (NICU) RSAD Robert Wolter Mongisidi yaitu pada sampel dinding, peralatan medis, udara siang dan udara sore.

Pada penelitian ini ditemukan 2 spesies Enterobacter yaitu Enterobacter cloacae dan Enterobacter aerogenes. Bakteri ini dapat menyebabkan infeksi nosokomial seperti pneumonia dan infeksi traktus urinarius. ${ }^{13}$ Telah dilaporkan bahwa bakteri ini adalah bakteri oportunistik yang banyak ditemukan dalam 3 dekade terakhir. Enterobacter cloacae banyak ditemukan di alam bebas dan bersifat patogen penyebab infeksi nosokomial meskipun mekanisme utama dan patogenesis belum sepenuhnya diketahui. ${ }^{15}$ Hasil penelitian menunjukkan Enterobacter cloacae ditemukan di sampel udara, dinding dan alat medis. Hal ini mungkin disebabkan karena kegiatan dan aktivitas di ruang Neonatal Intensive Care Unit (NICU) RSAD Robert Wolter Mongisidi tidak terkontrol dan kurangnya pengawasan terkait dengan kebersihan dan sterilitas ruangan.

Sama seperti penelitian infeksi nosokomial di ruang Neonatal Intensive Care Unit (NICU) Singapore General Hospital pada tahun 2012, Staphylococcus $s p$ merupakan bakteri kedua terbanyak yang ditemukan pada penelitian ini. ${ }^{16}$ Staphylococcus spditemukan pada sampel lantai dan udara di ruang Neonatal Intensive Care Unit (NICU) RSAD Robert Wolter Mongisidi.

Selain Enterobacter, bakteri Gram negatif lain yang ditemukan adalah Klebsiella pneumoniae, Serratia liquefaciens, Serratia marcescens, dan Escherichia coli. Berdasarkan National Nosocomial Infections Surveillance 
System,Escherichia coli dan Klebsiella pneumonia merupakan bakteri Gram negatif paling banyak yang menyebabkan infeksi nosokomial dan resisten terhadap antibiotik Sefalosporin generasi ke-3. ${ }^{17}$ Pada penelitian ini Escherichia coli ditemukan pada sampel tempat tidur bayi berhubungan dengan kotoran atau tinja bayi yang berasal dari popok.

Bakteri Gram negatif lainnya yaitu Serratia marcescens dan Serratia liquefaciens. Kedua bakteri ini ditemukan di perabotan ruangan dan udara. Hasil penelitian tahun 2007 tentang kejadian sepsis neonatal di RSAB Harapan Kita Jakarta menunjukkan bahwa bakteri penyebab utama sepsis neotanal adalah Serratia marcescens. Kejadian infeksi yang paling tinggi ditemukan pada hari ke 3-5 bahkan pada bayi dengan antibiotik sebelumnya. Secara keseluruhan sebagian besar kejadian infeksi tersebut disebabkan oleh bakteri Gram negatif dalam hal ini Serratia marcescens kemudian diikuti Klebsiella pneumoniae. ${ }^{18}$

\section{SIMPULAN}

Berdasarkan hasil penelitian pola bakteri aerob yang berpotensi menyebabkan infeksi nosokomial di ruang Neonatal Intensive Care Unit (NICU) RSAD Robert Wolter Mongisidi Manado dapat disimpulkan bahwa:

1. Dari 29 sampel ditemukan 9 spesies bakteri yaitu Enterobacter cloacae, Staphylococcus sp, Bacillus subtilis, Klebsiella pneumoniae, Serratia liquefaciens, Serratia marcescens, Enterobactr aerogenes, Neisseria sp, Eschericia coli.

2. Enterobacter cloacae merupakan bakteri yang terbanyak ditemukan.

\section{SARAN}

1. Agar pada penelitian selanjutnya dilakukan uji kepekaan antibiotik bakteri aerob penyebab infeksi nosokomial di ruang Neonatal Intensive Care Unit (NICU)

2. Sterilisasi ruang perawatan, perabotan ruangan, peralatan medis, dan udara di ruang Neonatal Intensive Care Unit (NICU) lebih diperhatikan

3. Pemeliharaan kebersihan lingkungan ruang perawatan harus lebih diupayakan

4. Perilaku sanitasi perorangan bagi tenaga medis maupun keluarga pasien perlu diperhatikan demi menghindari terjadinya infeksi silang

\section{DAFTAR PUSTAKA}

1. Widodo D, Irwanto R. Infeksi Nosokomial. Dalam: Setiawati S, Alwi I, Sudoyo AW, Simadibrata M, Setiyohadi B, Syam AF. Buku Ajar Ilmu Penyakit Dalam. Edisi 6. Jakarta: Pusat Penerbitan Ilmu Penyakit Dalam; 2014.p.682-91.

2. Staf Pengajar Fakultas Kedokteran Universitas Indonesia. Mikrobiologi Kedokteran. Edisi revisi. Tangerang: Binarupa Aksara. h.75-76

3. Brito DVD, Brito CS, Resende DS, Moreira J, Abdallah VOS, Filho PPG. Nosocomial infections in a Brazilian neonatal intensive care unit.Revista da sociedade Brasileira de medicina tropical 2010;43:633-7

4. Kasper DL, Hauser SL, Jameson JL, Fauci AS, Longo DL, Loscalzo J. editors. Harrison's Principles of Internal Medicine. $19^{\text {th }}$ Edition. New York: Mc Graw Hill Education. 2015.

5. Soedarmo SSP, Garna H, Hadinegoro SRS, Satari HI, editors. Buku Ajar Infeksi dan Pediatri Tropis. Edisi ke2. Jakarta: Badan Penerbit IDAI. 2012.h.478-96.

6. Nugraheni R, Suhartono, Winarni S. Infeksi Nosokomial di RSUD Setjonegoro Kabupaten Wonosobo. Media Kesehatan Masyarakat In/donesia. 2012;11.

7. Rotti G, Sjattar E, Budu. Hubungan Fungsi Manajemen Kepala Ruangan dengan Pelaksanaan Pencegahan dan Pengendalian Infeksi di Ruang Rawat Inap RSUP Prof. DR. Dr. R. D. Kandou Manado. JST Kesehatan. 2014;4:69-77.

8. Kliegman RM, Behrman RE, Jenson HB, Stanton BF, editors. Nelson 
Textbook of Pediatrics. $18^{\text {th }}$ Edition. Philadelphia: Saunders Elsevier; 2007.

9. Carolina A, Castro AB, Girao JE, Militao MA, Ribeiro CB, Tavora LGF. Risk factors for nosocomial infection in a brazilian neonatal intensive care unit. BJID 2008; 12:75-9

10. Alatas F, Satari H, Chair I, Rohsiswatmo R, Munasir Z, Windiastuti E. Gambaran Epidemiologi infeksi nosokomial aliran darah pada bayi baru lahir. Sari Pediatri. 2007;9:80-6

11. Rukmono ST, G Hikmatyar. Kualitas Mikrobiologi Udara di Ruang Neonatal Intensive Care Unit (NICU) Rumah Sakit Umum Daerah Dr. H. Abdul Moeloek Bandarlampung. MAJORITY (Medical Journal of Lampung University). 2015;4:143-8.

12. Saleh M, Rares FES, Soeliongan S. Pola Bakteri Aerob Infeksi Nosokomial Pada Ruangan Neonatal Intensive Care Unit (NICU) BLU RSUP Prof. DR. Dr. R. D. Kandou Manado. eBm. 2015;3.
13. Irianto K. Mikrobiologi medis. Bandung: Alfabeta; 2013. h. 10613

14. Brooks GF, Butel JS, Morse SA. Jawetz, Melnick \& Adelberg Mikrobiologi Kedokteran. Edisi ke-23. Jakarta: EGC; 2008

15. Regli AD, Pages JM. Enterobacter aerogenes and Enterobacter cloacae versatile bacterial pathogenns confronting antibiotic treatment.Frontiers In Microbiology. 2015;6:1-10

16. Carolin JJ, Lian WB, Yeo CL.Nosocomial Infections (Late Onset Sepsis) in the Neonatal Intensive Care Unit (NICU).Proceedings of Singapore Healthcare. 2012;21:238-44

17. Gaynes R,Edwards JR,NNIS. Overview of Nosocomial Infections Caused by Gram-Negative Bacilli. Clinical Infectious Diseases. 2005;41:848-54

18. Lusyati S, Saue PJJ. Sepsis Neonatal di NICU RSAB Harapan Kita Jakarta. Sari Pediatri. 2007; 9(3):173-177. 